\title{
Duplex-RT-PCR assay for the simultaneous detection and discrimination of Brome mosaic virus and Cocksfoot mottle virus in cereal plants
}

\author{
Katarzyna Trzmiel ${ }^{1}$ (1)
}

Received: 21 April 2021 / Accepted: 8 June 2021 / Published online: 16 June 2021

(c) The Author(s) 2021

\begin{abstract}
Brome mosaic virus (BMV) and cocksfoot mottle virus (CfMV) are pathogens of grass species including all economically important cereals. Both viruses have been identified in Poland therefore they create a potential risk to cereal crops. In this study, a duplex-reverse transcription-polymerase chain reaction (duplex-RT-PCR) was developed and optimized for simultaneous detection and differentiation of BMV and CfMV as well as for confirmation of their co-infection. Selected primers CfMVdiag-F/CfMVdiag-R and BMV2-F/BMV2-R amplified 390 bp and 798 bp RT-PCR products within coat protein $(\mathrm{CP})$ region of CfMV and replicase gene of BMV, respectively. Duplex-RT-PCR was successfully applied for the detection of CfMV-P1 and different Polish BMV isolates. Moreover, one sample was found to be co-infected with BMVML1 and CfMV-ML1 isolates. The specificity of generated RT-PCR products was verified by sequencing. Duplex-RT-PCR, like conventional RT-PCR, was able to detect two viruses occurring in plant tissues in very low concentration (as low as $4.5 \mathrm{pg} / \mu \mathrm{L}$ of total RNA). In contrast to existing methods, newly developed technique offers a significant time and cost-saving advantage. In conclusion, duplex-RT-PCR is a useful tool which can be implemented by phytosanitary services to rapid detection and differentiation of BMV and CfMV.
\end{abstract}

Keywords BMV · CfMV · Diagnostics · Duplex-RT-PCR $\cdot$ Co-infection $\cdot$ Cereal plants

\section{Introduction}

Brome mosaic virus (BMV) is typical member of the Bromovirus genus in the Bromoviridae family with tripartite genome. RNA1 and RNA2 are associated with virus replication and encode $1 \mathrm{a}$ and 2 a proteins, respectively while $5^{\prime}$ part of RNA3 encode movement protein (MP). Coding sequence of coat protein (CP) is located on subgenomic RNA4 [1]. The virus is widely distributed and viral infections have been confirmed in North America, South Africa and Europe [2]. Due to the broad range of its hosts [3] to which the virus can be easily transmitted mechanically or by insect vectors (mainly beetles but also dagger nematodes and aphids) [4], as well as the presence of infectious BMV particles in

Katarzyna Trzmiel

k.trzmiel@iorpib.poznan.pl

1 Department of Virology and Bacteriology, Institute of Plant Protection-National Research Institute (IPP-NRI), ul. W1. Węgorka 20, 60-318 Poznań, Poland irrigation runoff from cereal commercial fields [5] the pathogen persistence in the environment can be assured. BMV is considered as a model for RNA virus biology [6]. However, despite a lot of information on its basic biology, virus harmfulness information and its impact on crop production is very limited. Generally, BMV has not been considered as a major pathogen so far [7]. Nonetheless, the studies performed by Hodge et al. [2] showed a significant, reaching up to $61 \%$, reduction in grain yield harvested from wheat plants infected with BMV-OH. The first information about BMV in Poland comes from 1999 [8]. The results of studies, conducted in 2012-2020, revealed BMV infections of various crop species, wild plants as well as presence of infectious virus particles in water samples taken from drainage ditches and canals surrounding commercial fields in Wielkopolska, Dolny Śląsk and Małopolska regions in Poland [5, 8].

The second virus, a new potential threat for cereal crops, is cocksfoot mottle virus (CfMV). This is single stranded RNA virus belonging to the Sobemovirus genus in the Solemoviridae family. The virus has positive singlestranded polycistronic RNA genome of $4082 \mathrm{nt}$ in size, 
encapsidated in a spherical particles of about $30 \mathrm{~nm}$ in diameter [9]. The 5' terminus of the RNA has a genomelinked protein (VPg) and the 3' end lacks a poly(A) tail [10]. The virus was first reported in Great Britain and then in other European countries (Denmark, Norway, France, Germany), Asia (Russia and Japan), North America (Canada, USA) and New Zealand [9]. In Poland CfMV was detected for the first time in 2016 [11]. The virus is easily mechanically transmitted with the sap of infected plants and by vectors-beetles (Oulema melanopus and O. gallaeciana) in non-persistent manner. CfMV induces lethal, severe or mild leaf mottle and stunting of infected plants [12]. It has relatively narrow host range. In nature, CfMV mainly infected and induced yield losses of Dactylis glomerata but it was revealed also in wheat and it could be artificial transmitted to other cereals [12, 13]. As in the case of BMV, also CfMV can become a new potential threat to wheat crops [13]. Since both viruses have morphologically identical spherical virions, are transmitted by the same vectors, and induce similar symptoms on infected plants, proper diagnostics of these viruses can be problematic. To date, detection of BMV and CfMV is based on biological tests, enzyme-linked immunosorbent assays (ELISA) or reverse-transcription-polymerase chain reactions (RT-PCR) [2, 5, 8, 11-19]. A multiplex-reverse transcription-polymerase chain reaction (multiplex-RTPCR) is the promising alternative for above mentioned techniques which has been developed for the rapid and efficient detection of many RNA viruses in one reaction $[5,20,21]$. For this purpose, in this study a duplexRT-PCR was developed and optimized for simultaneous detection, and differentiation of BMV and CfMV and verification of their co-infection in cereal plants.

\section{Material and methods}

The studies were conducted with total RNA isolated from barley cv. Bażant infected with several BMV and CfMVP1 isolates collected in 2013-2020 from different locations in Wielkopolska, Dolny Śląsk and Małopolska regions of Poland (Table 1). The plants were mechanically inoculated with tissue from symptomatic leaves ground with $0.05 \mathrm{M}$ potassium phosphate buffer ( $\mathrm{pH}$ 7.0) containing carborundum and kept in insect proof glasshouse, in standard conditions ( $16 \mathrm{~h}$ of light and $8 \mathrm{~h}$ of darkness at $23{ }^{\circ} \mathrm{C}$ ). RNA from healthy barley $\mathrm{cv}$. Bażant plants was used as a negative control. Total RNA was extracted using the Total RNA Purification Kit Novazym (Novazym, Poznań, Poland) according to the manufacturer's protocol approximately 14 days after inoculation. The RNA concentration and quality were estimated using a NanoDrop 2000 spectrophotometer (Nanodrop Technologies, Delawere, USA). For BMV detection BMV2-F/BMV2-R primer pair [17] corresponding to genome sequence coding fragment of RNA-dependent RNA polymerase (RdRp) have been chosen (Table 2). The second pair of oligonucleotides (CfMVdiag-F/CfMVdiag-R) was designed by the Primer3 software (http://bioinfo.ut.ee/ primer3-0.4.0/) [22] based on complete genome sequence of Russian CfMV isolate (L40905). The primers permit the amplification of a fragment of CP coding sequence of CfMV (Table 2). The selected oligonucleotides were used with a Transcriptor One-step RT-PCR Kit (Roche, Mannheim, Germany). In order to determine the optimal conditions of duplex-RT-PCR assay the different combinations of primers concentration and different temperatures of annealing were used. The reactions contained $10 \mu \mathrm{L}$ of $5 \times \mathrm{RT}$-PCR Reaction Buffer, $1 \mu \mathrm{L}$ of Transcription Enzyme Mix, $2 \mu \mathrm{L}$ of primer pairs (in various tested concentrations: $0.6 \mu \mathrm{M}$ or $0.4 \mu \mathrm{M}$ or

Table 1 Description of virus isolates used in this study

\begin{tabular}{lllll}
\hline Isolate name & Geographical origin & Host & Collection date & Accession No. \\
\hline BMV-Sz & Szelejewo & Triticale & 2013 & MW581058 \\
BMV-Sr & near Środa Wielkopolska & Zea mays & 2013 & MW581059 \\
BMV-Sosn & Sośnicowice & Poa annua & 2016 & MW581061 \\
BMV-ML1 & Gorzyń & Dactylis glomerata & 2014 & MW581062 \\
BMV-ML2 & Poznań & Hordeum murinum & 2015 & MW581065 \\
BMV-Choj & Chojno & Bromus hordeaceus & 2017 & MW581057 \\
BMV-R & Szelejewo & Water from ditch surrounding fields & 2017 & MW581064 \\
BMV-Ch1 & Choryń & Water from ditch surrounding fields & 2017 & MW581067 \\
BMV-DBS & Bielany & Water from ditch surrounding fields & 2020 & MW581066 \\
BMV-B & near Kraków & Triticum aestivum & 2020 & MW568015 \\
BMV-Kon & Konin & Poa annua & 2016 & MW568017 \\
CfMV-P1 & Sośnicowice & Dactylis glomerata & & KX880413 \\
\hline
\end{tabular}


Table 2 Primers used in duplexRT-PCR

\begin{tabular}{llll}
\hline Primer's name & Primer sequence $\left(5^{\prime}-3^{\prime}\right)$ & $\begin{array}{l}\text { Product size } \\
(\mathrm{bp})\end{array}$ & References \\
\hline BMV2-F & CTATAGCAAAGCGCTTTCGT & & \\
BMV2-R & CAAACGTAGGGCACACTAGGG & 798 & Trzmiel et al. [17] \\
$\begin{array}{l}\text { CfMVdiag-F } \\
\text { CfMVdiag-R }\end{array}$ & GATGGAGCCAGTCTCTCGAC & & This study \\
\hline
\end{tabular}

$0.3 \mu \mathrm{M}), 1 \mu \mathrm{L}$ of isolated RNA and they were supplemented to a final volume of $50 \mu \mathrm{L}$ with sterile water. Reverse transcription was performed at $50{ }^{\circ} \mathrm{C}$ for $30 \mathrm{~min}$. The initial denaturation was performed at $94{ }^{\circ} \mathrm{C}$ for $7 \mathrm{~min}$, followed by 40 cycles of denaturation at $94^{\circ} \mathrm{C}$ for $10 \mathrm{~s}$, annealing at different tested temperatures of 56,58 and $60{ }^{\circ} \mathrm{C}$ for $30 \mathrm{~s}$, elongation at $68{ }^{\circ} \mathrm{C}$ for $60 \mathrm{~s}$, and a final elongation at $68^{\circ} \mathrm{C}$ for $7 \mathrm{~min}$. RT-PCR products were verified by electrophoretical separation in $1 \%$ agarose gel containing Midori Green DNA stain (Nippon Genetics Europe GmbH, Düren, Germany) with 100-bp DNA ladder (Novazym, Poznań, Poland). Moreover, additional RT-PCR tests with BMVML1 sample were performed to verify natural co-infection with studied viruses. Selected CfCP-F1/CfCP-R2 [14] and CfMV-F/CfMV-R [11] primer pairs amplify specific DNA product of $776 \mathrm{pb}$ and $655 \mathrm{pb}$ in size, respectively. They enable to obtain complete $\mathrm{CP}$ coding sequence of CfMV. The reactions were performed following authors recommendations. The specificity of generated RT-PCR products was confirmed by sequencing. Amplified DNA fragments were excised from the gel and purified using Wizard ${ }^{\circledR}$ SV Gel and PCR Clean-Up System (Promega, Madison, WI, USA) and subjected to sequencing by Sanger method in external company (Genomed S.A., Warsaw, Poland). The obtained nucleotide sequences were edited and compiled in BioEdit software [23] and then were compared with the others deposited in GenBank database by BlastN. In the last step, the sensitivity of duplex-RT-PCR and conventional RT-PCR assays was estimated and compared. For this purpose $1 \mu \mathrm{L}$ of tenfold serial dilutions (from $4.5 \times 10^{2}$ to $4.5 \times 10^{-5} \mathrm{ng} / \mu \mathrm{L}$ of total RNA) of BMV-ML1, sample co-infected with BMV and CfMV, were used as template for reactions. The detection limit was verified by electrophoresis as described above.

\section{Results and discussion}

Based on published results [2, 13] BMV and CfMV can be a new emerging threat for cereal crops. To date CfMV has been detected only in one locations in Poland [11] however, since first detection of BMV in 1999 in Poland, its presence has been reported in different regions of the country [5, 8]. Taking into account the possibility of further spread of the studied pathogens, the designing of specific diagnostic technique as the first step in the successful management of the diseases is needed. Existing diagnostic methods for BMV [2, 5, 8, 17-19] and CfMV [11, 13-16] have their limitations. ELISA is a time-consuming and laborious technique while conventional RT-PCR assay is able to detect only individual virus species in a single reaction. This limitations can be overcame using duplex-RT-PCR. In contrast to mentioned above methods, a newly presented here technique allows for the simultaneous detection and differentiation of BMV and CfMV in single reaction. In conclusion, this duplex-RT-PCR

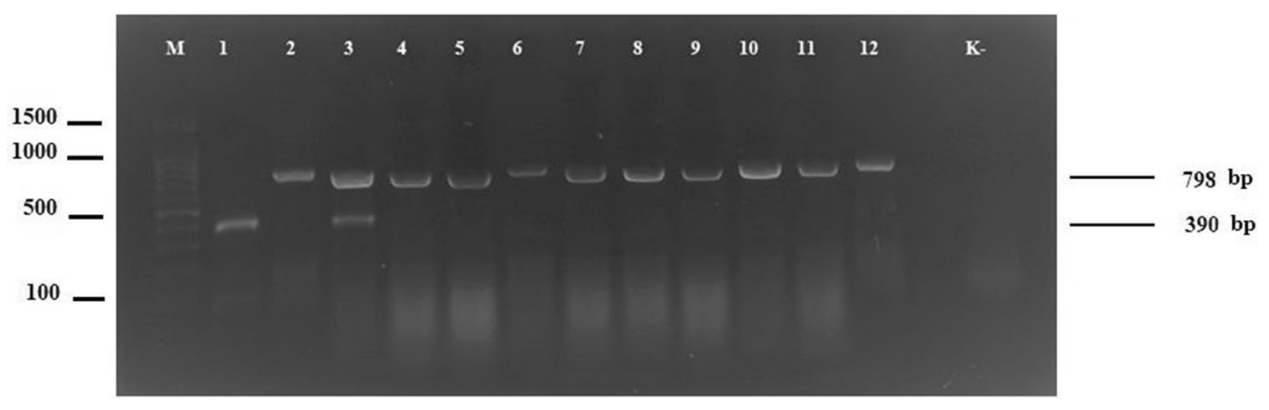

Fig. 1 Analysis of duplex-RT-PCR products on agarose gel; lane M-100-bp DNA ladder (Novazym, Poznań, Poland), lanes: 1-CfMVP1，2-BMV-K，3-BMV-ML1，4-BMV-Sosn, 5-BMV-Sze, 6-BMV-
ML2, 7-BMV-Choj, 8-BMV-Sr, 9-BMV-R, 10-BMV-DBS, 11-BMV$\mathrm{S}$, 12-BMV-Pk, lane K- negative control (total RNA from healthy barley) 

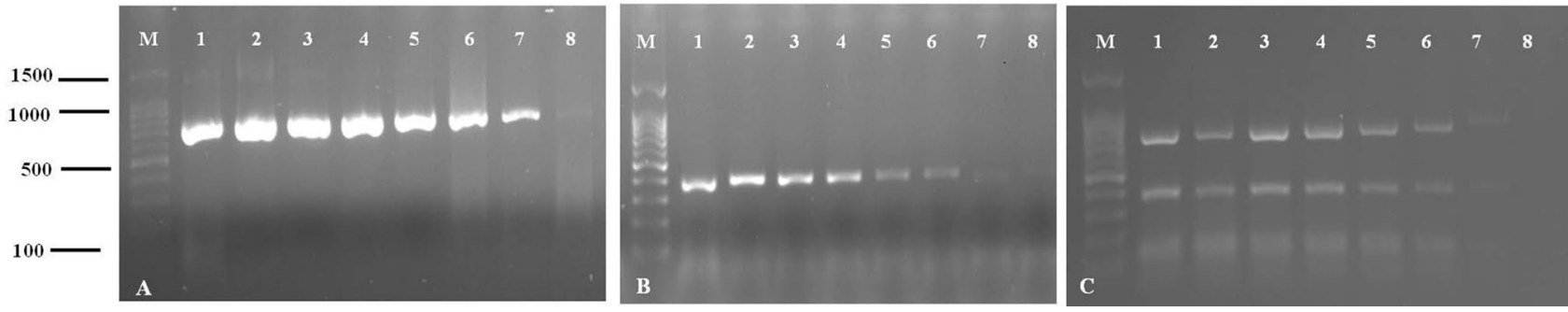

Fig. 2 A comparison of sensitivity of conventional RT-PCR and duplex-RT-PCR techniques for BMV and CfMV detection. The figures present the electrophoretic separation of a RT-PCR BMV products, b RT-PCR CfMV products and c duplex-RT-PCR products.

offers a significant time and cost-saving advantage. For the best amplification efficiency and specificity for both viruses, duplex-RT-PCR reactions were performed at different temperatures and the optimal annealing temperature was found to be $56{ }^{\circ} \mathrm{C}$. Similarly, the analyses confirmed that the sensitivity of the reaction was correlated with the final concentration of the primers and balanced amplification for both pathogens was achieved when the primers concentrations were $0.3 \mu \mathrm{M}$ for BMV and $0.6 \mu \mathrm{M}$ for CfMV. The amplified products were obtained only for tested CfMV and BMV samples whereas no amplicons were produced for the samples of healthy barley and wheat plants. Additionally, for BMV-ML1 sample both specific RT-PCR products were obtained (Fig. 1). Sequencing of chosen duplex-RT-PCR products (798 bp for BMV and $390 \mathrm{bp}$ for CfMV) confirmed their specificity. Comparative nucleotide sequences analyses showed high similarity of studied BMV and CfMV isolates and others deposited in GenBank database (over 99\% identity). Moreover, the results of additional comparative analysis of complete CP nucleotide sequence of CfMV, amplified with BMV-ML1 sample, showed a 95\% similarity with the corresponding fragments of the nucleotide sequences of CfMV-No (DQ680848), CfMV-Oxford (FJ669143); 94\% with CfMV-Ohio (MF621330), CfMV-Russia (L40905), CfMV-Japan (AB040447) and only 93\% with CfMV-P1 (KX880413). The results confirm the distinctiveness of the "newly detected" CfMV-ML1 isolate. Complete CP coding sequence of CfMV-ML1 (762 nt long) was deposited in the NCBI GenBank database (MW 147114). Developed here diagnostic system verifies the results obtained in the past and confirms the second location of CfMV in Poland with the presence of natural co-infection of BMV-ML1 and CfMV-ML1 in Wielkopolska region. This sample was used in next comparative analyses. Conventional RT-PCR reactions were able to detect BMV and CfMV in as little as $0.45 \mathrm{pg} / \mu \mathrm{l}$ and $4.5 \mathrm{pg} / \mu \mathrm{l}$ of total RNA, respectively (Fig. 2a, b). Duplex-RT-PCR was capable to detect viruses in as low as $4.5 \mathrm{pg} / \mu \mathrm{l}$ of total RNA (Fig. 2c). Although duplex-RTPCR was tenfold less sensitive than conventional RT-PCR but it was still able to detect two viruses occurring in plant
Fragments of 798 bp and 390 bp of BMV and CfMV were amplified from tenfold dilution of total RNA starting at $450 \mathrm{ng} / \mu \mathrm{L}$. Lanes: M-100 bp DNA ladder (Novazym), 1-8 - correspond to serial tenfold dilution of total RNA

tissues in very low concentration. This technique allows for effective detection of co-infections with BMV and CfMV as early as 14 days after inoculation. Obtained results are comparable with those reported by other authors [21]. In conclusion, mentioned above results indicates that optimized in this study technique is useful diagnostic tool that can be routinely used by phytosanitary services for rapid identification of studied viral infection in cereals. To our knowledge, this is the first report of duplex-one-step-RT-PCR assay for detection of BMV and CfMV.

Funding The study was supported by the Polish Ministry of Education and Science, statutory activity project: WIB03 as well as by the National Science Centre (NCN), Poland under Grant No. 2018/02/X/ NZ9/02474.

Data availability The data of this study are available from the author upon request.

\section{Declarations}

Conflict of interest The author declares that there is no conflict of interest.

Ethical approval This article does not contain any studies with human participants or animals which were performed by any of the authors.

Open Access This article is licensed under a Creative Commons Attribution 4.0 International License, which permits use, sharing, adaptation, distribution and reproduction in any medium or format, as long as you give appropriate credit to the original author(s) and the source, provide a link to the Creative Commons licence, and indicate if changes were made. The images or other third party material in this article are included in the article's Creative Commons licence, unless indicated otherwise in a credit line to the material. If material is not included in the article's Creative Commons licence and your intended use is not permitted by statutory regulation or exceeds the permitted use, you will need to obtain permission directly from the copyright holder. To view a copy of this licence, visit http://creativecommons.org/licenses/by/4.0/. 


\section{References}

1. Bujarski J, Figlerowicz M, Gallitelli D, Roossinck MJ, Scott SW (2012) Family Bromoviridae. In: King AMQ, Lefkowitz E, Adams M, Carstens EB (eds) Virus taxonomy: ninth report of the International Committee on taxonomy of viruses. Elsevier, London, pp 965-976

2. Hodge BA, Salgado JD, Paul A, Stewart LR (2019) Characterization of an Ohio isolate of Brome mosaic virus and its impact on the development and yield of soft red winter wheat. Plant Dis 103:1101-1111. https://doi.org/10.1094/PDIS-07-18-1282-RE

3. Lane LC (1974) The Bromoviruses. In: Lauffer MA, Bang FB, Maramorosch K, Smith KM (eds) Advances in virus research, vol 19. Academic Press, New York/San Francisco/London, pp $151-220$

4. Mise K, Poscai E (2004) Brome mosaic. In: Lapierre H, Signoret PA (eds) Viruses and virus diseases of Poaceae (Gramineae). INRA, Paris, pp 735-739

5. Jeżewska M, Trzmiel K, Zarzyńska-Nowak A (2019) Detection of infectious Brome mosaic virus in irrigation ditches and draining strands in Poland. Eur J Plant Pathol 1:1-8. https://doi.org/10. 1007/s10658-018-1531-7

6. Scholthof KBG, Adkins S, Czosnek H, Palukaitis P, Jacquot E, Hohn T, Hohn B, Saunders K, Candresse T, Ahlquist P, Hemenway C, Foster GD (2011) Top 10 plant viruses in molecular plant pathology. Mol Plant Pathol 12:938-954. https://doi.org/10. 1111/j.1364-3703.2011.00752

7. Lane LC (1981) Bromoviruses. In: Kurstak E (ed) Handbook of plant virus infections and comparative diagnosis. Elsevier, Amsterdam, pp 333-376

8. Trzmiel K, Zarzyńska-Nowak A, Lewandowska M, Szydło W (2016) Identification of new Brome mosaic virus (BMV) isolates systematically infecting Vigna unguiculata L. Eur J Plant Pathol 145:233-238. https://doi.org/10.1007/s10658-015-0830-5

9. Munthe T (2004) Cocksfoot mottle. In: Lapierre H, Signoret PA (eds) Viruses and virus diseases of Poaceae (Gramineae). INRA, Paris, pp 746-748

10. Tamm T, Truve E (2000) RNA-binding activities of cocksfoot mottle sobemovirus proteins. Virus Res 66(2):197-207. https:// doi.org/10.1016/s0168-1702(00)00125-8

11. Trzmiel K, Jeżewska M (2017) First report of Cocksfoot mottle virus infecting Dactylis glomerata in Poland. Plant Dis 101:6. https://doi.org/10.1094/PDIS-11-16-1573-PDN

12. Serjeante $P(1967)$ Some properties of cocksfoot mottle virus. Ann Appl Biol 59:31-38. https://doi.org/10.1111/j.1744-7348.1967. tb04414

13. Hodge BA, Paul PA, Stewart LR (2018) First report of Cocksfoot mottle virus infecting wheat (Triticum aestivum) in Ohio. Plant Dis 102(2):464. https://doi.org/10.1094/PDIS-08-17-1224-PDN
14. Alderman SC, Martin RC, Gilmore BS, Martin RR, Hoffman GD, Sullivan CS, Anderson NP (2016) First report of Cocksfoot mottle virus infecting Dactylis glomerata in Oregon and the United States. Plant Dis 100(5):1030. https://doi.org/10.1094/ PDIS-09-15-1017-PDN

15. Delmiglio C (2008) The incidence and phylogenetic analysis of viruses infecting New Zeland's native grasses. $\mathrm{PhD}$ thesis, University of Auckland, New Zealand

16. Delmiglio C, Pearson MN, Lister RA, Guy PL (2010) Incidence of cereal and pasture viruses in New Zealand's native grasses. Ann Appl Biol 157:25-36. https://doi.org/10.1111/j.1744-7348.2010. 00406

17. Trzmiel K, Wielkopolan B, Lewandowska M (2015) Using RT-PCR assay for the detection of Brome mosaic virus (BMV) in cereal leaf beetle (Oulema melanopus L.). Prog Plant Prot 55(4):494-497. https://doi.org/10.14199/ppp-2015-082

18. Urbanavičiené L, Žižyté M (2012) Identification of Brome mosaic virus in cocksfoot (Dactylis glomerata L.) and meadow fescue (Festuca pratensis Huds.) in Lithuania. Agric 99(2):167-172

19. Zvyaginceva DD, Beloshapkina OO, Lopatkin AA, Shneider YA, Morozova ON (2021) Cereal viruses-brome mosaic virus: prevalence and diagnostics. IOP Conf Ser Earth Environ Sci 663:012036. https://doi.org/10.1088/1755-1315/663/1/012036

20. Malmstrom CM, Shu R (2004) Multiplexed RT-PCR for streamlined detection and separation of barley and cereal yellow dwarf viruses. J Virol Methods 120:69-78. https://doi.org/10.1016/j. jviromet.2004.04.005

21. Zarzyńska-Nowak A, Hasiów-Jaroszewska B, Korbecka-Glinka G, Przybyś M, Borodynko-Filas N (2018) A multiplex RT-PCR assay for simultaneous detection of Tomato spotted wilt virus and Tomato yellow ring virus in tomato plants. Can J Plant Pathol 40(4):580-586. https://doi.org/10.1080/07060661.2018.1503195

22. Rosen S, Skaletski HJ (2000) Primer3 on the WWW for general use and for biologist programmers. In: Krawetz S, Misenes S (eds) Bioinformatics methods and protocols: method in molecular biology. Humana Press, Totowa, pp 365-386. https://doi.org/10. 1385/1-59259-192-2\%3A365

23. Hall TA (1999) BioEdit: a user-friendly biological sequence alignment editor and analysis program for Windows 95/98/NT. Nucleic Acids Symp Ser 41:95-98

24. Hull R, Fargette D (2005) Genus Sobemovirus. In: Fauquet CM, Mayo MA, Maniloff J, Desselberger U, Ball LA (eds) Virus taxonomy, 8th report of the International Committee on the taxonomy of viruses. Elsevier, London, pp 885-890

Publisher's Note Springer Nature remains neutral with regard to jurisdictional claims in published maps and institutional affiliations. 